[計測自動制 御学会論文集]

[ Vol.55, No.8, 485/490 (2019) ]

\title{
せいめい望遠鏡の分割主鏡制御の概念設計
}

\author{
軸 屋一 郎*·上 野 幸 紀*·木 野＼cjkstart勝** \\ 栗 田 光樹夫** ・ 山 田 克 彦***
}

\section{Conceptual Design for Control System of Segmented Primary Mirror in SEIMEI Telescope}

\author{
Ichiro JiKUYA*, Koki UenO*, Masaru KINO**, \\ Mikio KURITA** and Katsuhiko YAMADA*** $^{* *}$
}

\begin{abstract}
A segmented mirror system is essential to realize extremely large telescopes. In this paper, we discuss the conceptual design for the control system of the segmented primary mirror in the SEIMEI telescope employing 18 segments, 72 sensors, and 54 actuators. Two types of control algorithms, Centralized Control System (CCS) and Distributed Control System (DCS), are presented. CCS drives all the segments by integrated information of all sensors and DCS drives each segment by individual information of local sensors, and they are expected to play complementary roles. The effectiveness of CCS and DCS are demonstrated by numerical simulations.
\end{abstract}

Key Words: active optics, position control, vibration control, telescope, segmented mirror

\section{1.はじめに}

天体望遠鏡は空間分解能向上と大集光力の要請から世界中 で大口径化が進んでいる ${ }^{1)}$. 大口径化のための一つの手法が 「分割主鏡」の技術である．分割主鏡とは分割鏡と呼ばれる複 数の独立した鏡を並べることで一枚の主鏡として機能させる 方式であり，巨大鏡の製作や輸送の困難を解決することがで きる，一方で，架台の熱変形・重力変形と風外乱などの影響 を受けて，観測時に分割鏡間の相対位置がずれてしまう問題 点がある.この問題点に対処する考え方は二つに大別される. 一つは, HET ${ }^{2)}$, 姉妹機の $\mathrm{SALT}^{3)}{ }^{3)} \mathrm{LAMOST}^{4)}$ などにお いて，精密な分割鏡制御を行なわず，簡素かつ安価な構造を 目指すことにより大集光力に特化する考え方である．もう一 つは, Keck 望遠鏡 ${ }^{5)}$ とその系列の望遠鏡において, 精密な分 割主鏡制御により各分割鏡で反射される光の位相を合わせる ことにより，大集光力と空間分解能力向上を両立させる考え 方である．分光観測など精密な観測を行なっていくためには， 分割主鏡制御による空間分解能力向上が必須であることはい うまでもない.

* 金沢大学理工研究域 金沢市角間

** 京都大学大学院理学研究科 京都市左京区北白川追分町

*** 大阪大学大学院工学研究科 吹田市山田丘 2-1

* Institute of Science and Engineering, Kanazawa University, Kakuma, Kanazawa

** Graduate school of Science, Kyoto University, Kitashirakawa-Oiwakecho, Sakyo-ku, Kyoto

*** Graduate School of Engineering, Osaka University, 2-1 Yamadaoka, Suita

(Received February 4, 2019)

(Revised April 22, 2019)
日本においても京都大学が中心となって, 東アジア最大級 となる「せいめい望遠鏡」を建設している，せいめい望遠鏡 でも分割主鏡が採用されており，分割主鏡制御による空間分 解能力向上を目指している. Keck 望遠鏡では六角形の分割鏡 が用いられているのに対し，せいめい望遠鏡では花弁型の分 割鏡が用いられており，その意味では世界初の試みといえる.

Keck 望遠鏡の分割主鏡制御では動特性を考慮した制御対 象のモデル化は行なっていない.アクチュエー夕位置とセン サ出力の間の静特性のみを考慮してモデル化を行ない, 積分 制御を施している ${ }^{6), 7)}$. 筆者らは日本独自の技術獲得を目的 として花弁型分割主鏡に対する相対位置制御を検討してきた. 先行研究では, 2 枚の分割鏡を並べてテストベッドを構成し て, システム同定を行ない, ローパスフィルタやノッチフィル 夕を用いたコントローラの設計について検討してきた ${ }^{8) \sim 10)}$.

本論文ではせいめい望遠鏡における分割主鏡制御の概念設 計を行なう。せいめい望遠鏡における分割主鏡制御の目的は, 天体観測中に 18 枚の分割鏡から構成される分割主鏡全体を 理想鏡面形状に保つことである.アクチュエータに内在する 積分器特性に起因する動特性と分割鏡の回転・並進とセンサ 出力の間の静特性の両方を考慮して制御対象の状態空間モデ ルを導出する。集中制御と分散制御という二通りの制御方式 を提案して，それぞれの手法により安定化を実現する.さら に，それぞれの手法の有効性をシミュレーションを通じて確 認し, 優劣を比較する. なお, 本論文の先行研究 ${ }^{11), 12)}$ と比 較すると行列の誘導 $l_{\infty^{-}}$ノルムを用いて制御性能を評価して いる点で定量的な議論が付加されている．また本論文で省略 された説明事項は文献 13)に記載されている。 


\section{2. モデリング}

\section{1 分割主鏡}

分割鏡は剛体としてモデル化され， 1 枚あたりの幅は約 $1 \mathrm{~m}$, 厚さは約 $50 \mathrm{~mm}$, 重量は約 $70 \mathrm{~kg}$ であり, 変形は考慮しない. 剛体には並進と回転の合計 6 自由度が存在するが，分割鏡を 背面から支える支持機構により 3 自由度は拘束されている. 残された自由度は 3 自由度あり，Fig. 1 の $\alpha, \beta, z$ として 表わされる， $\alpha$ は分割鏡の半径方向に沿った回転の自由度を 表わし， $\beta$ は分割鏡の円周方向に沿った回転の自由度を表わ し, $z$ は分割鏡の面外方向の並進の自由度を表わす.

分割主鏡は 18 枚の分割鏡から構成される.Fig. 2 は分割 主鏡の鏡面を見下万す方向から表示している。 1 番から 6 番 までは内周セグメントを表わし， 7 番から 18 番までは外周セ グメントを表わす．内周セグメントの内側の円は内周リング を表わす．内周リングは鏡としての役割は果たさないが，分 割鏡制御においては基準面の役割を果たす。18 枚の分割鏡の それぞれに $\alpha, \beta, z$ の自由度が存在するので, 分割主鏡全体 としては合計 54 自由度が存在する。

分割主鏡の制御を行なうために，各分割鏡の背面から 3 個 のアクチュエータが取り付けられている。各アクチュエータ はステッピングモータと減速器を組み合わせて構成され, 変 位を調整可能である．3 個のアクチュエータの変位を調整す ることにより $\alpha, \beta, z$ の自由度を制御可能である． 18 枚の 分割鏡のそれぞれにアクチュエータが 3 個取り付けられてい るので，合計 54 個のアクチュエータが取り付けられている.

分割主鏡の理想鏡面形状からの偏差を計測するために，天 体観測開始前と天体観測中では異なるセンサを用いる．天体 観測開始前はシャックハルトマンセンサで回転 $\alpha, \beta$ を計測 し，位相カメラで並進 $z$ を計測する。アクチュエータを用い て各分割鏡の位置を補正することにより，天体観測開始時に は理想鏡面形状であることを想定する。天体観測開始時に理 想鏡面形状であったとしても，天体観測中に架台の熱変形・ 重力変形と風外乱により分割主鏡面が乱されるので, 天体観 測中の常時補正が必要となる。天体観測中は距離センサを用 いて分割鏡と分割鏡の間の相対位置を計測する。具体的には, 分割鏡と内周リングの間もしくは分割鏡と分割鏡の間に相対 位置を計測する渦電流式距離センサが取り付けられており, 分割主鏡全体としては 72 個取り付けられている.

分割主鏡制御の目的は天体観測中に分割主鏡の全体を理想 鏡面形状に保つことである. 合計 72 自由度の距離センサの 出力をもとに, 合計 54 自由度のアクチュエータを用いて, 合 計 54 自由度の回転・並進を零に収束させる安定化問題とし て定式化される，距離センサが計測するのは相対位置のみで あり，理想鏡面形状からの絶対的な偏差を計測できないこと に分割主鏡制御の難点がある。

\section{2 制御対象}

分割主鏡制御問題における制御対象のモデル化を行なう. ダイナミクスとしてステッピングモータの速度入力に起因す

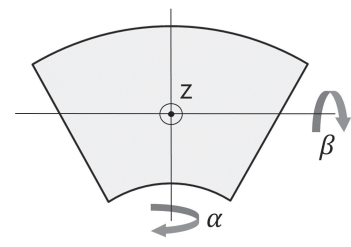

Fig. 1 Segmented mirror

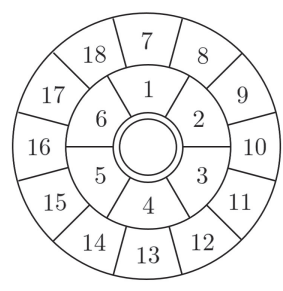

Fig. 2 Overall view of segmented mirrors
る積分器特性のみを考慮する。高周波側の機械的な共振特性 などは考慮しない。このとき制御対象は以下に示すようにモ デル化される。

$$
\left\{\begin{array}{l}
\dot{x}=u \\
y=C x
\end{array}\right.
$$

ここで $x \in \mathbb{R}^{54}$ は状態を表わし， $\alpha_{k}, \beta_{k}, z_{k}$ を組として添 字 $k=1,2, \cdots, 18$ の増加順に構成される. $y \in \mathbb{R}^{72}$ は出力 を表わし，各センサの出力から構成される．紙面の都合上具 体的な構成は割愛する. $u \in \mathbb{R}^{54}$ は入力を表わし， $\dot{\alpha}_{k}, \dot{\beta}_{k}$, $\dot{z}_{k}$ から構成される。

状態 $x$ は絶対的な偏差を表わし, 出力 $y$ は相対位置を表わす. 状態 $x$ と出力 $y$ は一対一に対応しないが, 行列 $C \in \mathbb{R}^{72 \times 54}$ により対応付けされている。後述するように各アクチュエー 夕への速度入力と $\dot{\alpha}_{k}, \dot{\beta}_{k}, \dot{z}_{k}$ は一致しないが, 变換行列 $M \in \mathbb{R}^{54 \times 54}$ を導入することにより対応付けが可能となる.

$$
\dot{a}=M u
$$

ここで $\dot{a} \in \mathbb{R}^{54}$ はアクチュエータへの速度入力から構成され るが，紙面の都合上具体的な構成は割愛する。

行列 $C$ と行列 $M$ の導出手順を以下に説明する。なお，各 種変数と各種定数は実機設計時の記号をそのまま用いる。添 字の規則性が煩雑となるので, 図中に例示される变数と定数 の関係に限定して考え方を説明する.

\section{3 行列 $C$ の導出}

行列 $C$ は幾何学的な評価により導出可能である。本節では 内周セグメント 1 を例として行列 $C$ の計算手順を例示する.

分割主鏡全体の理想鏡面形状は非球面形状であるが曲率は 十分に小さい. 分割主鏡制御における基準面を内周リングを 通る平面として，内周セグメント 1 は平板で近似する。 $\alpha_{1}$, $\beta_{1}, z_{1}$ のすべてが 0 であるときに内周セグメント 1 が基準面 上にあり，いずれかが 0 でないときに基準面上にないことを 意味する．分割主鏡に比べてアクチュエータの許容ストロー ク幅は十分に小さいので， $\alpha_{1}, \beta_{1}, z_{1}$ は十分に小さいとみな すことができる。

Fig. 3 は内周セグメント 1 を鏡面を見下ろす方向から表示 している. Fig. 3 中の四角はセンサの位置を表わし，黒丸は 鏡の中心を表わす。 $-y_{T 0}, x_{S 1},-y_{S 1},-y_{T 2}, y_{S 3}$ は設計值 から定まる定数であり，鏡の中心に対するセンサ $S_{0,0 a}, S_{1,1}$, 
$S_{2,2}, S_{1,3}$ の位置を規定する距離を表わす.なお, $y_{T 0}, x_{S 1}$, $y_{S 1}, y_{T 2}, y_{S 3}$ は実機設計時に向き付けされて導入された記 号であるが, $y_{T 0}, y_{S 1}, y_{T 2}$ については向きを補正するために 符号を反転させている.

センサは取り付け側の分割鏡を基準として隣り合った分割 鏡との高さの差を出力する．すなわち，隣り合った分割鏡に はセンサと対向する点に対向板が取り付けられており，対向 板の高さからセンサの高さを引いて出力する，たとえば，七 ンサ $S_{0,0 a}$ は内周リングに取り付けられており, 鏡 1 の対向 板 $T_{1,0}$ の高さから $S_{0,0 a}$ の高さを引いて出力する. 内周リン グは基準面と一致して高さは 0 なので, $S_{0,0 a}$ は $T_{1,0}$ の高さ を出力する。一方, センサ $S_{1,1}$ は鏡 1 に取り付けられてお り, 内周リングの対向板 $T_{0,1 b}$ の高さから $S_{1,1}$ の高さを引い て出力するので, $S_{1,1}$ は $S_{1,1}$ の高さの符号を反転させて出力 する. 同様に，センサ $S_{1,3}$ は鏡 1 に取り付けられており，鏡 2 の対向板の高さから $S_{1,3}$ の高さを引いて出力する．七ンサ $S_{2,2}$ は鏡 2 に取り付けられており, 鏡 1 の対向板の高さから $S_{2,2}$ の高さを引いて出力する.

Fig. 4 は内周セグメント 1 を $\beta$-軸方向（円周方向）から 表示している．位置関係を幾何学的に評価して線形近似する と, $S_{0,0 a}$ と $\beta_{1}, z_{1}$ は以下のように関係づけられる.

$$
S_{0,0 a}=y_{T 0} \sin \beta_{1}+z_{1} \simeq y_{T 0} \beta_{1}+z_{1}
$$

Fig. 5 は内周セグメント 1 を $\alpha$-軸方向（半径方向）から 表示している，位置関係を幾何学的に評価して線形近似する と, $S_{1,1}$ と $\alpha_{1}, \beta_{1}, z_{1}$ は以下のように関係づけられる.

$$
\begin{aligned}
S_{1,1} & =-x_{S 1} \sin \alpha_{1}-y_{S 1} \sin \beta_{1}-z_{1} \\
& \simeq-x_{S 1} \alpha_{1}-y_{S 1} \beta_{1}-z_{1}
\end{aligned}
$$

(3) 式と (4) 式の $\alpha_{1}, \beta_{1}, z_{1}$ に関する係数が行列 $C$ の成 分となる. (3) 式の係数は行列 $C$ の 1 行目を構成し, 非零成 分が 2 個, 零成分が 52 個となる. (4) 式の係数は行列 $C$ の 2 行目を構成し, 非零成分が 3 個, 零成分が 51 個となる。ほ かのセンサやセグメントについても同様に幾何学的に評価す ると行列 $C$ の全体を導出できる. 行列 $C$ は零・非零成分が 混在する疎な行列であり，七ンサが十分に配置されているの で列フルランクとなる。
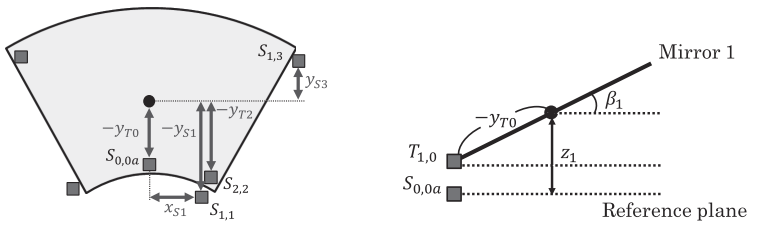

Fig. 3 Sensor arrangement in Fig. 4 segmented mirror 1

Sectional view from $\beta$ axis to calculate $S_{0,0 a}$

\section{4 行列 $M$ の導出}

行列 $M$ は幾何学的な評価により導出可能である. 以降では 内周セグメント 1 を例として行列 $M$ の計算手順を例示する.

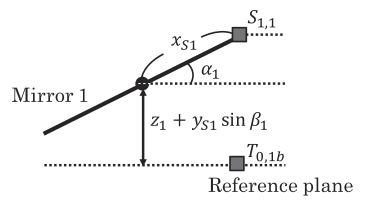

Fig. 5 Sectional view from $\alpha$-axis to calculate $S_{1,1}$

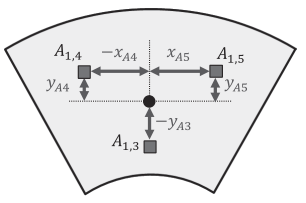

Fig. 6 Actuator arrangement in segmented mirror 1
Fig. 6 は内周セグメント 1 を鏡面を見下ろす方向から表示 している. Fig. 6 中の四角はアクチュエータの位置を表わし, 黒丸は鏡の中心を表わす. $-y_{A 3}, y_{A 4}, y_{A 5},-x_{A 4}, x_{A 5}$ は設 計值から定まる定数であり，鏡の中心に対するアクチュエー 夕 $A_{1,3}, A_{1,4}, A_{1,5}$ の位置を規定する距離を表わす。なお, $y_{A 3}, y_{A 4}, y_{A 5}, x_{A 4}, x_{A 5}$ は実機設計時の記号をそのまま用い ており, $y_{A 3}, x_{A 4}$ については向きを補正するために符号を反 転させている。

各アクチュエータはステッピングモータの送りネジ出力を てこで減速して $z$ 軸方向に変位を生成する．分割鏡が基準面 に一致するときの変位を 0 として,$z$ 軸正方向への変位を正 とする。

アクチュエータを駆動したときのアクチュエータの変位と 分割鏡の変位の関係を幾何学的に評価して線形近似すると, アクチュエータの変位 $A_{1,3}, A_{1,4}, A_{1,5}$ と $\alpha_{1}, \beta_{1}, z_{1}$ は以 下のように関係づけられる。

$$
\begin{aligned}
A_{1,3} & =y_{A 3} \sin \beta_{1}+z_{1} \simeq y_{A 3} \beta_{1}+z_{1} \\
A_{1,4} & =x_{A 4} \sin \alpha_{1}+y_{A 4} \sin \beta_{1}+z_{1} \\
& \simeq x_{A 4} \alpha_{1}+y_{A 4} \beta_{1}+z_{1} \\
A_{1,5} & =x_{A 5} \sin \alpha_{1}+y_{A 5} \sin \beta_{1}+z_{1} \\
& \simeq x_{A 5} \alpha_{1}+y_{A 5} \beta_{1}+z_{1}
\end{aligned}
$$

(5)～(7) 式の両辺の時間微分を計算すると，アクチュエー 夕への速度入力 $\dot{A}_{1,3}, \dot{A}_{1,4}, \dot{A}_{1,5}$ と $\dot{\alpha}_{1}, \dot{\beta}_{1}, \dot{z}_{1}$ の関係が得 られる。したがって (5) (7) 式の $\alpha_{1}, \beta_{1}, z_{1}$ に関する係数 が行列 $M$ の成分を構成する.ほかのセグメントに関しても 同様に評価すると (2) 式が得られ，行列 $M$ の全体を導出でき る. 行列 $M$ は零・非零成分が混在する疎な行列であり，フ ルランクとなる。

\section{3. 制御 方式}

\section{1 定数出カフィードバック制御則}

(1) 式の制御対象に対する制御則を提案する。行列 $C$ は列 フルランクなので, $C$ の擬似逆行列 $C^{\dagger}$ を出力 $y$ にかけると 状態 $x$ を再構成できる。したがって定数出力フィードバック 制御則により擬似的に状態フィードバック制御則を実現でき，

(1) 式を安定化可能であることがわかる.

$$
u=F y
$$

行列 $F \in \mathbb{R}^{54 \times 72}$ は定数出力フィードバックゲインを表わす. 
以降では F の選定方法について具体的に考察していく.

\section{2 集中制御}

$C$ の擬似逆行列 $C^{\dagger}$ としてムーアペンローズの擬似逆行列 を選び，さらにスカラゲイン $K>0$ の自由度を付与する.

$$
F=-K\left(C^{T} C\right)^{-1} C^{T}
$$

この制御方式を集中制御（Centralized Control System; CCS) と呼ぶ.

\section{3 分散制御}

望遠鏡組み立て時の設計データからのずれに起因して, 望 遠鏡実機の行列 $C$ と設計データから得られる行列 $C$ は乘離 する可能性がある. 望遠鏡の追尾運動に伴い重力の作用が変 化すると望遠鏡架台が変形してセンサ位置が変化すると想定 され，行列 $C$ の值も変化する可能性がある. そこで行列 $C$ の正確な值に依存しない制御手法も望まれる.

本節では，七ンサ情報から $\alpha_{k}, \beta_{k}, z_{k}$ を擬似的に計算し， それぞれに対して個別に擬似状態フィードバック制御を行な うことを考える。たとえば，内周セグメント 1 に関する閉ルー プシステムが以下に一致するように出力フィードバックゲイ ン $F$ の一部を定めることとする.

$$
\left\{\begin{array}{l}
\dot{\alpha}_{1}=-K_{\alpha, 1} \frac{-S_{0,0 a}-S_{1,1}}{x_{S 1}} \\
\dot{\beta}_{1}=-K_{\beta, 1} \frac{-S_{2,2}-S_{1,3}}{-y_{T 2}+y_{S 3}} \\
\dot{z}_{1}=-K_{z, 1} S_{0,0 a}
\end{array}\right.
$$

ここで, 右辺の $\frac{-S_{0,0 a}-S_{1,1}}{x_{S 1}}$ と $\frac{-S_{2,2}-S_{1,3}}{-y_{T 2}+y_{S 3}}$ は隣り合ったセン サ間の高さの差をセンサ間の距離で割ることによって $\alpha_{1}$ と $\beta_{1}$ の近似值を与える． $S_{0,0 a}$ は内周セグメントの内周リング に対する高さによって $z_{1}$ の近似值を与える。これらの近似に より，個別に擬似状態フィードバックが実現される状況を意 図している，さらにほかの内周セグメントと外周セグメント に拉いても同様に考え，出力フィードバックゲイン $F$ の全体 を定めることができる．紙面の都合上具体的な表記について は割愛する。この制御方式を分散制御（Distributed Control System; DCS）と呼ぶ. (10) 式も右辺は設計データを含む が, 集中制御と比較してゲイン調整の自由度が増えており, 特 定の設計デー夕の変動を吸収できる余地が増している。ただ し, 以降のシミュレーションでは $\alpha_{k}, \beta_{k}, z_{k}$ に関するスカ ラゲイン $K_{\alpha, k}>0, K_{\beta, k}>0, K_{z, k}>0$ はそれぞれ添字 $k$ によらず共通の $K_{\alpha}, K_{\beta}, K_{z}$ としてゲインチューニングを 行なうこととする.

なお，何通りかの近似值を選定してシミュレーションによ る比較を行ない (10) 式を選んだが，ほかにも工夫の余地があ ることを付記する。たとえば，本論文では外周セグメントの 内周セグメントに対する高さによって外周セグメントの $z_{k}$ の 近似值を与えたが，外周セグメントの内周リングに対する高 さによって外周セグメントの $z_{k}$ の近似值を与えた場合には 外周セグメント側の速度入力が大きくなり過ぎてゲインを上
げることができなかった。

\section{4 評価方法}

集中制御則ではスカラゲイン $K$ を任意に大きくして過渡応 答を早くすることが可能である。分散制御則でも，閉ループ システムが安定となるゲイン $K_{\alpha}, K_{\beta}, K_{z}$ の組み合わせが 見つかれば，比率を保って大きさを任意に多くすることによ り，過渡応答を早くすることが可能である。しかし，ゲイン を大きくしすぎると過大な制御入力を要し，アクチュエータ の飽和にかかってしまう.

本節ではこれらのトレードオフを考慮したゲインの評価方 法を考慮する．閉ループシステムのブロック線図は Fig. 7 に 与えられる。(1) 式と (8) 式から構成される閉ループシステ ムの初期值応答を解き，(2) 式を適用すると各時刻における アクチュエータへの速度入力が定まる。

$$
\dot{a}(t)=M F C e^{F C t} x(0)
$$

初期值 $x(0)$ の各成分はそれぞれ以下の不等式を満たすものと 仮定する.

$$
\begin{aligned}
& -\alpha_{0} \leq \alpha_{k}(0) \leq \alpha_{0} \\
& -\beta_{0} \leq \beta_{k}(0) \leq \beta_{0} \\
& -z_{0} \leq z_{k}(0) \leq z_{0}
\end{aligned}
$$

ここで $\alpha_{0}, \beta_{0}, z_{0}$ はそれぞれ添字 $k$ に依存しない定数を表 わす.このとき入力 $\dot{a}(t)$ の各成分 $\dot{a}_{k}(t)$ が各時刻 $t \geq 0$ にお いてそれぞれ以下の不等式を満たすならばアクチュエータへ の速度入力の制限にかからない.

$$
-a_{0} \leq \dot{a}_{k}(t) \leq a_{0}
$$

ここで $a_{0}$ はアクチュエータの許容速度入力幅を表わし, 添字 $k$ に依存しない定数を表わす。このとき $(12) \sim(14)$ 式を満た す任意の $x(0)$ に対して $\dot{a}(t)$ が $(15)$ 式を満たすことは行列の 誘導 $l_{\infty^{-}}$ノルムを用いて評価することができ，時刻 $t \geq 0$ に おいて以下の不等式が成り立つことと同值である.

$$
l(t):=\sup _{\|v\|_{\infty} \leq 1, v \neq 0}\left\|W_{2}^{-1} M F C e^{F C t} W_{1} v\right\|_{\infty}<1
$$

ここで $\|v\|_{\infty}$ はベクトル $v$ の $l_{\infty^{-}}$ノルムを表わす. $W_{1}$ は $\alpha_{0}$, $\beta_{0}, z_{0}$ を交互に並べて得られる対角行列であり， $W_{2}=a_{0} I$ である。

(16) 式の不等式が成り立つことを解析的に保証することは 困難であるが，閉ループシステムが安定化されている状況な ら有限時間区間上で $l(t)$ を数值的に調べることにより確認 可能である. 行列 $X$ の誘導 $l_{\infty}$ ノノルムは成分 $x_{i, j}$ を用いて $\|X\|_{\infty}=\max _{i} \sum_{j}\left|x_{i, j}\right|$ として計算できるので, 各時刻 $t \geq 0$ において $l(t)$ を数值的に評価すれば良い. 次章ではせいめい 望遠鏡の諸元に基づき提案手法を検証する.

4. シミュレーション

\section{1 条件設定}

せいめい望遠鏡の設計デー夕を公称值として行列 $C$ と行列 


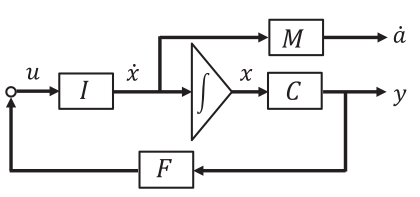

Fig. 7 Block diagram of the closed loop system

$M$ を計算することができる，紙面の都合上詳細は割愛する． 本実験の予備実験において, 観測時に想定される風速の 1.5 倍 となる $15 \mathrm{~m} / \mathrm{s}$ の風がドーム内に吹き込んで生じる乱流を想定 して, テストベッドに負荷をかけたときに分割鏡間に $1000 \mathrm{~nm}$ 程度の相対位置誤差が生じた ${ }^{14)} .1000 \mathrm{~nm}$ の相対位置誤差を $\alpha, \beta, z$ の取りうる最大值に換算すると $\alpha$ は $0.0000037 \mathrm{rad}$, $\beta$ は $0.0000022 \mathrm{rad}, z$ は $0.001 \mathrm{~mm}$ 程度の変動として解釈 できる. そこで $\alpha_{0}=0.0000037 \mathrm{rad}, \beta_{0}=0.0000022 \mathrm{rad}$, $z_{0}=0.001 \mathrm{~mm}$ とおく. アクチュエータに許容される最大速 度入力は $8.9 \mathrm{~mm} / \mathrm{s}$ であり, 減速器を通した後の最大速度入 力は約 $0.30 \mathrm{~mm} / \mathrm{s}$ に換算される. そこで $a_{0}=0.30 \mathrm{~mm} / \mathrm{s}$ と おく.

せいめい望遠鏡では各センサの計測値の二乗平均平方根 (RMS) が $50 \mathrm{~nm}$ 以下となることを制御目標の一つとする. しかし現時点ではせいめい望遠鏡に対する風外乱のモデル化 手法が確立されていないので, シミュレーションでは外乱を 考慮しない. 代わりに, 次式が成り立つ時刻をもって初期值 応答の収束時間を評価する。

$$
\mathrm{RMS}=\sqrt{\frac{1}{72} \sum_{i=1}^{72}\left(y_{i}\right)^{2}} \leq 50 \mathrm{~nm}
$$

\section{2 集中制御におけるシミュレーション結果}

3.2 節で考えた集中制御においてシミュレーションを行な う. 比例ゲインは $K=1301 / \mathrm{s}$ とした.

まず, 4.1 節で設定した $\alpha, \beta, z$ の条件下におけるアクチュ エータの最大速度入力を誘導 $l_{\infty}$ ノルムを用いて評価する.

Fig. 8 より 4.1 節の条件下でアクチュエータへの速度入力が $0.30 \mathrm{~mm} / \mathrm{s}$ 以下となることを保証できることがわかる.

つぎに，初期值を 4.1 節に述べた範囲内で選定してシミュ レーションを行なった．このときのアクチュエータへの速度 入力 $u$ の 54 成分を重福きすると Fig. 9 のようになった. 紙面の都合上，本図を含めて重ね書きをしたときの添え字は 割愛する，速度入力が $0.30 \mathrm{~mm} / \mathrm{s}$ 以下になっていることが確 認できる。これは誘導 $l_{\infty}$ ノルムを用いて計算した結果に合 致する.このときの初期值応答を $\alpha_{k}, \beta_{k}, z_{k}$ ごとに 18 成分 を重ね書きすると Fig. 10～Fig. 12 となり，分割鏡の相対 位置が収束することが確認できる。また (1) 式と (17) 式を用 いて各時刻ごとに RMS を計算すると， $0.0808 \mathrm{~s}$ でセンサの 計測值の RMS が $50 \mathrm{~nm}$ 以下となることが確認できる．紙面 の都合上 RMS のグラフは割愛する.

4.3 分散制御におけるシミュレーション結果

3.3 節で考えた分散制御のシミュレーション結果を例示する. 比例ゲインは $K_{\alpha}=75 \mathrm{~mm} / \mathrm{s}, K_{\beta}=75 \mathrm{~mm} / \mathrm{s}, K_{z}=251 / \mathrm{s}$

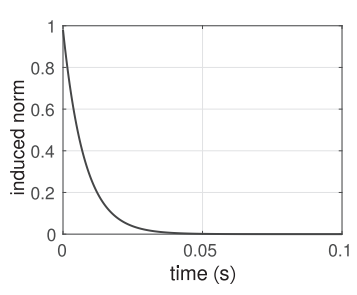

Fig. 8 Induced $l_{\infty}$-norm in CCS

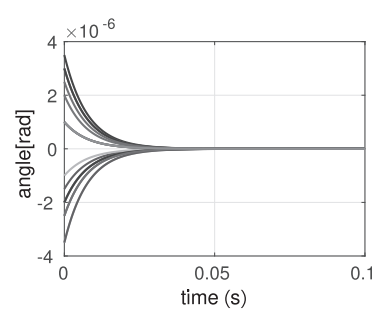

Fig. 10 Initial response of $\alpha_{k}$ in CCS (rad)

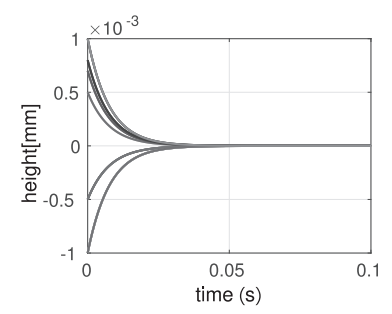

Fig. 12 Initial response of $z_{k}$ in CCS $(\mathrm{mm})$

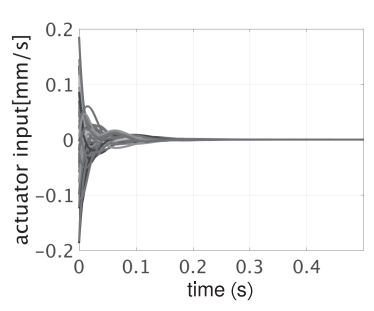

Fig. 14 Input in DCS $(\mathrm{mm} / \mathrm{s})$

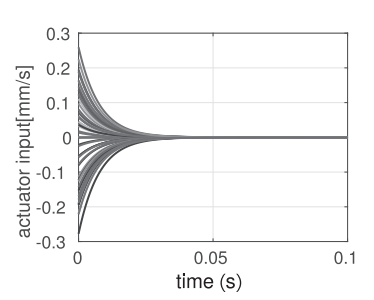

Fig. 9 Input in CCS $(\mathrm{mm} / \mathrm{s})$

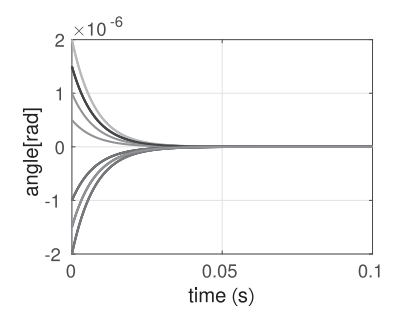

Fig. 11 Initial response of $\beta_{k}$ in CCS (rad)

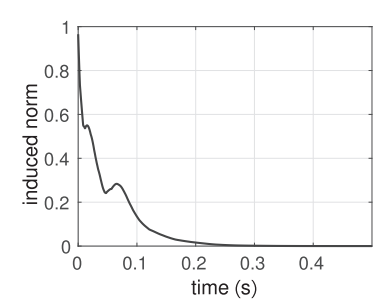

Fig. 13 Induced $l_{\infty}$-norm in DCS

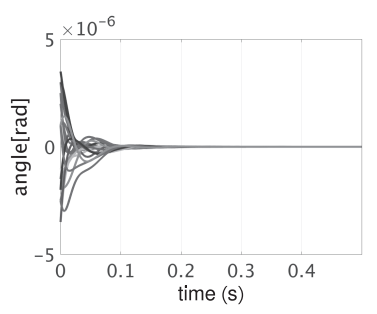

Fig. 15 Initial response of $\alpha_{k}$ in DCS (rad)
とした.

まず，集中制御の場合と同様に，4.1 節で設定した $\alpha, \beta, z$ の条件下に扔けるアクチュエータの最大速度入力を誘導 $l_{\infty}$ ノルムを用いて評価する．Fig. 13より 4.1 節の条件下でア クチュエータへの速度入力が $0.30 \mathrm{~mm} / \mathrm{s}$ 以下となることを保 証できることがわかる。

つぎに初期值を 4.1 節に述べた範囲内で選定してシミュレー ションを行なった. Fig. 14より, アクチュエータへの速度入 カが $0.30 \mathrm{~mm} / \mathrm{s}$ 以下になっていることが確認できる.これは 誘導 $l_{\infty^{-}}$ノルムを用いて評価した結果に合致する．このとき の初期值応答を $\alpha_{k}, \beta_{k}, z_{k}$ ごとに重ね書きすると Fig. 15

Fig. 17 となり, 分割鏡の相対位置が収束することが確認で きる。また (1) 式と (17) 式を用いて各時刻ごとに RMS を計 


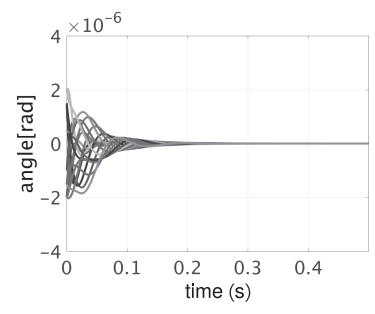

Fig. 16 Initial response of $\beta_{k}$ in DCS (rad)

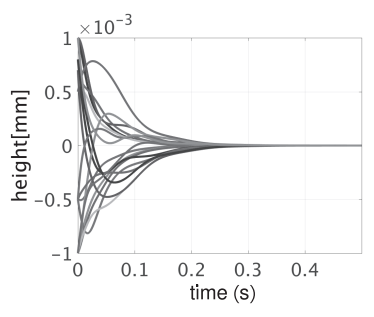

Fig. 17 Initial response of $z_{k}$ in DCS $(\mathrm{mm})$
算すると， $0.4865 \mathrm{~s}$ でセンサの計測值の RMS が $50 \mathrm{~nm}$ 以下 となることが確認できる。紙面の都合上 RMS のグラフは割 愛する.

\section{5. おわりに}

本稿ではせいめい望遠鏡に用いられる分割主鏡全体の相対 位置制御方式について検討を行なった。集中制御と分散制御 という制御手法を提案した。そしてシミュレーションにより 有効性を検討し，大きな負荷がかかる状況でもアクチュエー 夕の速度入力制限を満たすようなフィードバックゲインの選 定が集中制御と分散制御のどちらにおいても可能であること を示した。ここで検討した集中制御と分散制御は行列 $C$ の精 度によって使い分けができる。集中制御では行列 $C$ の擬似逆 行列を考えるなど行列 $C$ の精度が制御に影響してくる，その ため, センサの正確な配置が得られる場合，つまり行列 $C$ を 正確に計算できる場合には，集中制御が有効だが，センサの 正確な配置が得られない場合には，分散制御も有効な方法に なるといえる，今後は望遠鏡実機に提案手法を搭載し，実際 の動作特性を検討していきたい.

\section{参 考 文 献}

1）木野，軸屋：分割鏡とその制御，計測と制御， 56-6, 449/454 (2017)

2) https://www.as.utexas.edu/mcdonald/het/het.html (参照 2018-01-16)

3）https://www.salt.ac.za (参照 2018-01-16)

4) http://www.lamost.org/public/?locale=en（参照 2018-0116)

5) http://www.keckobservatory.org (参照 2018-01-16)

6) R.C. Jared, A.A. Arthur, S. Andreae, A.K. Biocca, R.W. Cohen, J.M. Fuertes, J. Franck, G. Gabor, J. Llacer, T.S. Mast, J.D. Meng, T.L. Merrick, R.H. Minor, J.T. Nelson, M. Orayani, P. Salz, B.A. Schaefer, C. Witebsky and W.M. Keck: Telescope segmented primary mirror active control system, Proc. SPIE, 1236, 996/1008 (1990)

7) D.G. MacMartin and G. Chanan: Measurement accuracy in control of segmented-mirror telescopes, Appl. Opt., 433, 608/615 (2004)

8）木野，軸屋，上野，山田， $3.8 \mathrm{~m}$ 望遠鏡開発グループ：分割主 鏡式望遠鏡に用いるナノメートル位置決め制御システムの開発 と駆動試験，第 17 回計測自動制御学会システムインテグレー ション部門講演会予稿集，2J2-2 (2016)

9）上野, 軸屋, 木野, 山田：分割主鏡式望遠鏡のための相対位置制 御系の初期設計，第 4 回制御部門マルチシンポジウム，1D1-3 (2017)

10）上野，軸屋，木野，山田：分割主鏡式望遠鏡の制御系設計にお
けるノッチフィルタの適用事例，平成 29 年度電気関係学会北 陸支部連合大会, H-8 (2017)

11）上野, 軸屋, 新村, 木野, 山田 : せいめい望遠鏡の分割鏡制御 の初期設計，第 61 回自動制御連合講演会，11B5 (2018)

12）上野, 軸屋, 新村, 木野, 山田 : せいめい望遠鏡の分割鏡全体 の制御方式の検討，第 19 回計測自動制御学会システムインテ グレーション部門講演会, 2D3-05 (2018)

13）上野幸紀：せいめい望遠鏡の分割主鏡のためのセンサ情報を用 いた位置制御，金沢大学大学院自然科学研究科電子情報科学専 攻修士論文 (2019 年 1 月 31 日)

14）木野 勝：セグメント主鏡制御装置の開発状況，第 37 回望 遠鏡技術検討会, http://www.kusastro.kyoto-u.ac.jp/psmt/ kentou/37th/37_kino.pdf (2015) (参照 2019-1-17)

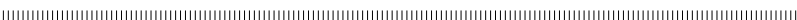

\section{[著 者 紹 介]}

軸 屋 一 郎 (正会員)

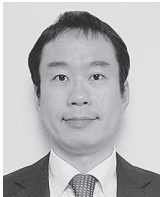

2001 年東京大学大学院工学系研究科博士課程 修了. Twente 大学, 名古屋大学, 金沢大学理工 研究域電子情報学系准教授を経て，2017 年より金 沢大学理工研究域フロンティア工学系准教授, 現 在に至る. 博士 (工学). 制御工学の教育と研究に 従事.

\section{上 野 幸 紀}

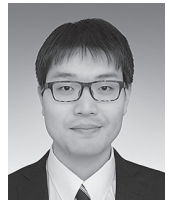

2017 年金沢大学理工学域電子情報学類卒業. 同 年金沢大学大学院自然科学研究科電子情報科学専 攻博士前期課程入学，現在に至る。分割主鏡式望 遠鏡に用いる制御系設計の研究に従事.

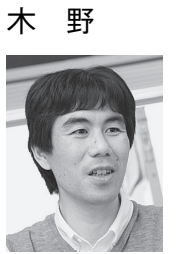

2009 年名古屋大学大学院理学研究科博士課程修 了. 名古屋大学大学院理学研究科研究員, 同寄付 講座助教, 京都大学大学院理学研究科特定助教を 経て, 2017 年より京都大学大学院理学研究科助教 となり現在に至る。博士 (理学)。せいめい望遠鏡 の開発をはじめ, 光学系とそれを応用した観測装 置の開発に従事してきた.

\section{栗 田 光樹夫（正会員）}

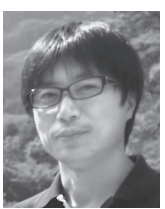

2005 年名古屋大学大学院理学研究科博士課程修 了, 博士 (理学). 2012 年上り京都大学大学院理 学研究科准教授となり現在に至る。10 年以上にわ たって数多くの成果を上げてきている IRSF $1.4 \mathrm{~m}$ 望遠鏡（名古屋大学を中心に，わが国が，南アフ リカ天文台サザーランド観測所に建設）の開発に たずさわって以降，望遠鏡を中心に観測装置の開 発を行なってきた。

\section{山田克 彦 (正会員)}

1980 年東京大学大学院工学系研究科修士課程修 了. 同年三菱電機（株） 入社，同社先端技術総合 研究所勤務を経て, 2005 年名古屋大学工学研究科 航空宇宙工学専攻教授, 2013 年大阪大学工学研究 科機械工学専攻教授, 現在に至る. 工学博士. 宇 宙機の力学と制御に関する研究開発に従事. 